\title{
Characterisation of illegally imported meat and meat products and identification of $E$. coli in the samples confiscated at the Croatian borders
}

\author{
Danijela Horvatek Tomić1*, Lidija Kozačinski², Maja Lukač ${ }^{1}$, Istvan Toth³, \\ Sandra Gutić ${ }^{4}$, and Estella Prukner-Radovčić ${ }^{1}$ \\ ${ }^{1}$ Department of Poultry Diseases with Clinic, Faculty of Veterinary Medicine, University of Zagreb, \\ Zagreb, Croatia \\ ${ }^{2}$ Department of Hygiene, Technology and Food Safety, Faculty of Veterinary Medicine, University of Zagreb, \\ Zagreb, Croatia \\ ${ }^{3}$ Veterinary Medical Research Institute, Hungarian Academy of Sciences, Budapest, Hungary \\ ${ }^{4}$ Veterinary and Food Safety Directorate, Ministry of Agriculture, Zagreb, Croatia
}

\begin{abstract}
HORVATEK TOMIĆ, D., L. KOZAČINSKI, M. LUKAČ, I. TOTH, S. GUTIĆ, E. PRUKNER-RADOVČIIĆ: Characterisation of illegally imported meat and meat products and identification of $E$. coli in the samples confiscated at the Croatian borders. Vet. arhiv 89, 123-132, 2019.
\end{abstract}

\section{ABSTRACT}

Prevention and control of foodborne diseases is an international public health goal. Legal imports of food of animal origin are monitored for contamination, and alerts are reported regularly, but food brought into the country illegally could represent a potential threat to consumers' health. In order to assess the level of the risk for public health from uncontrolled imported food of animal origin entering the Republic of Croatia, 83 meat samples were collected at 6 border points between Croatia and third countries. The origins of all confiscated samples were third countries, and the final destinations were EU countries and Switzerland. The weight of the confiscated samples ranged from $500 \mathrm{~g}$ to $108 \mathrm{~kg}$. Special attention was focused on the presence of $E$. coli and its antimicrobial susceptibility. From altogether 83 confiscated meat samples, 8 were positive for $E$. coli. Although STEC and/or O157, as well as multidrug resistant $E$. coli were not found in the examined samples, illegally imported meat should be monitored continuously to prevent possible foodborne bacterial infections.

Key words: meat; confiscation; borders; Escherichia coli

\footnotetext{
${ }^{*}$ Corresponding author:

Assist. Prof. Danijela Horvatek Tomić, Faculty of Veterinary Medicine, University of Zagreb, Department of Poultry Diseases with Clinic, Heinzelova 55, 10000 Zagreb, Croatia, Phone: +385 12390 281; Fax: +385 12390 410; E-mail: horvatek@vef.hr
} 


\section{Horvatek Tomić et al.: Characterisation and prevalence of $E$. coli in confiscated meat samples}

\section{Introduction}

Microbial food safety is still a major concern in many European Union (EU) member states due to repeated outbreak episodes and contamination problems. The global influence and growth of the European market affect the food supply chain that is becoming increasingly complex and requires professional risk management systems to ensure consumer protection. Legal imports are well monitored for contamination, and alerts are registered through the RASFF notification systems (ANONYM., 2008). On the other hand, the amount of meat and dairy products confiscated from passengers in the EU in the 2009-2011 period was between 273 and 280 tons, respectively (ANONYM., 2012a; as cited by JANSEN et al., 2016). Also, between 67,003 and 81,397 of illegal consignments of meat and dairy products were noticed during the 2009-2011 period (ANONYM., 2012a; as cited by JANSEN et al., 2016). The reported weight of the illegally imported food per passenger at German airports was on average between 3.22 $\mathrm{kg}$ and $3.44 \mathrm{~kg}$ (JANSEN et al., 2016) and at Paris airport, the largest confiscated meat package weighed $51 \mathrm{~kg}$ (CHABER et al., 2010).

Uncontrolled food imports present the risk of transferring new strains of different pathogens from third countries to the EU (BEUTLICH et al., 2015; NAGY et al., 2015; RODRÍGUEZ-LÁZARO et al., 2015; CHABER and CUNNIGHAM, 2016). Many particular species of bacterial pathogens, such as Salmonella, Campylobacter or Listeria, have been isolated from transcontinental or local outbreaks (NEWELL et al., 2010; CIOLACU et al., 2015). According to the EFSA report for 2016, zoonotic foodborne diseases are still of major concern for public health (ANONYM., 2017). One of the bacteria that also raises an alert is Escherichia coli. In particular Verocytotoxigenic E. coli (VTEC) O157:H7 and Shiga toxin-producing E. coli (STEC) may colonize the gastrointestinal tract of different animals, and potentially contaminate the meat during processing (TAMMINEN et al., 2018; WILSON et al., 2018). The bacteria VTEC was isolated from food samples confiscated at German airports, as well as other pathogenic bacteria, such as Salmonella, Listeria and Yersinia (BEUTLICH et al., 2015). E. coli, isolated from animals and food products, resistant to numerous antimicrobial agents could represent a reservoir of resistant genes that could be transferred to opportunistic pathogenic bacteria (SÁENZ et al., 2004; SUNDE, 2005; BEN SLAMA et al., 2010). Major concerns are raised by the antimicrobial resistance of commensal E. coli in poultry production, especially due to the fact that broilers have become one of the most important meat sources worldwide (ROTH et al., 2018). According to the ANONYM. (2018), E. coli isolated from broilers, fattening turkeys and their meat, was frequently highly resistant to ampicillin, (fluoro)quinolones, tetracyclines and sulfonamides. The level of multi-drug resistant (MDR) E. coli was also overall very high (50.2\%) (ANONYM., 2018). MDR E. coli was also observed in food samples in the EU (JAKOBSEN et al., 2010; NAGY et al., 2015; JANS et al., 2018). The geographical position of the Republic of Croatia is such that it is located on a corridor where many travellers transit through on their way 
D. Horvatek Tomić et al.: Characterisation and prevalence of E. coli in confiscated meat samples

to the EU. Also, the borderline that the Republic of Croatia has with third countries is longer than 1300 kilometres, of which 1052 kilometres is with Bosnia and Herzegovina alone. Illegal import of food of animal origin entering Croatia from third countries may represent a risk to public and animal health.

In order to assess the level of risk and to detect the hazard, movement of illegally imported meat and meat products was tracked at 6 land border points with third countries (Bosnia and Herzegovina, Serbia, and Montenegro). The total weight and the country of origin and final destination were recorded. Testing of the microbiological quality of confiscated meat samples was carried out with specific attention paid to the presence and determination of $E$. coli and its antimicrobial susceptibility.

Since public awareness of the global dimension of food safety is increasing, the main aim of this research was to investigate if the food of animal origin, mainly different meat products, found illegally imported into Croatian territory, may represent a potential risk for public and animal health.

\section{Material and methods}

Collection of samples. A total of 83 samples of different meat and meat products were confiscated by border veterinary inspectors in the period from November 2013 to May 2014 (Table 1.). The samples were collected at four road border points between Croatia and Bosnia and Herzegovina, one road border point between Croatia and Serbia, and one road border point between Croatia and Montenegro. For all confiscated samples, data were recorded about the total quantity of the product, the origin and final destination, as well as information about whether the product was intended for personal or commercial use. All confiscated samples were sent immediately, or after storage at $+4{ }^{\circ} \mathrm{C}$ for a maximum of 24 hours, to the laboratories at the Faculty of Veterinary Medicine of the University of Zagreb.

Microbiological examination. E. coli bacteria were detected by standard bacterial examination and the appropriate ISO methods. The taxonomic classification of the isolated bacteria was based on colony morphology, and microscopic and biochemical characteristics. Gram staining, catalase and oxidase reactions were conducted as described by BROWN (2005).

The isolated E. coli were sent to the Veterinary Medical Research Institute of the Hungarian Academy of Sciences, where they were further tested according to ISO guidelines 16654:2001 (ANONYM., 2001) for O157 VTEC or ISO/ TS13136:2012 for non-O157 VTEC (ANONYM, 2012b).

Antimicrobial sensitivity testing using the disc diffusion method was conducted according to the instructions given by Clinical and Laboratory Standards Institute (CLSI). The antimicrobial agents used were as follows: gentamicin, amikacin, streptomycin, tobramycin, kanamycin, ampicillin, ceftazidime, aztreonam, amoxicillin, imipenem, cefotaxime, chloramphenicol, nalidixic acid, ciprofloxacin, sulphamethoxazole, 
D. Horvatek Tomić et al.: Characterisation and prevalence of E. coli in confiscated meat samples

sulphonamides, tetracycline and trimethoprim. E. coli ATCC 25922 was used as the referent strain.

\section{Results and discussion}

In total, 83 samples of different meat and meat products were confiscated at the Croatian border points (Table 1). All confiscated samples arrived from non-European countries. The final destination for all the confiscated products were EU countries and Switzerland. The majority of samples were processed (dry) meat products (sausages, ham, ribs and bacon). The veterinary inspectors also confiscated fresh and frozen meat products (beef, poultry and pork). Although the confiscated meat products were designated for personal use and were found in personal luggage, the weight of samples from $500 \mathrm{~g}$ to $108 \mathrm{~kg}$ raised the concern that some of those food items were not intended for personal use only, but could also be placed on Croatian local markets, or consumed by a larger group of people in other EU countries (i.e. $20 \mathrm{~kg}$ of dry cured pork greaves, or $108 \mathrm{~kg}$ of dry cured pork bacon).

Table 1. Description of confiscated meat and meat products at Croatian border crossings

\begin{tabular}{|l|c|c|}
\hline Sample & $\begin{array}{c}\text { Number of confiscated } \\
\text { samples }\end{array}$ & $\begin{array}{c}\text { Total amount of the original } \\
\text { sample }\end{array}$ \\
\hline Processed (dry) meat products & \multicolumn{2}{|c|}{} \\
\hline Dry cured pork ham & 17 & $5.5-33.4 \mathrm{~kg}$ \\
\hline Dry cured pork sausage & 12 & $4.0-20.0 \mathrm{~kg}$ \\
\hline Dry cured pork bacon & 9 & $8.8-108.0 \mathrm{~kg}$ \\
\hline Dry cured pork meat & 7 & $10.0-26.0 \mathrm{~kg}$ \\
\hline Dry cured beef meat & 4 & $7.0-33.0 \mathrm{~kg}$ \\
\hline Dry cured pork rib & 3 & $3.0-6.10 \mathrm{~kg}$ \\
\hline Dry cured pork greaves & 2 & $8.0-20.0 \mathrm{~kg}$ \\
\hline Other pork products & 2 & $6.15-10.0 \mathrm{~kg}$ \\
\hline Dry cured sheep meat & 1 & $2.20 \mathrm{~kg}$ \\
\hline Fresh meat samples & \multicolumn{2}{|l|}{} \\
\hline Beef & 8 & $3.0-14.4 \mathrm{~kg}$ \\
\hline Chicken & 7 & $0.5-14.4 \mathrm{~kg}$ \\
\hline Pork & 2 & $10.0-25.0 \mathrm{~kg}$ \\
\hline Veal & 1 & $4.5 \mathrm{~kg}$ \\
\hline Minced meat & 1 & $6.1 \mathrm{~kg}$ \\
\hline Frozen meat samples & \multicolumn{2}{|}{} \\
\hline Chicken & 5 & $4.0-10.0 \mathrm{~kg}$ \\
\hline Beef & 2 & $8.5-10.0 \mathrm{~kg}$ \\
\hline
\end{tabular}


D. Horvatek Tomić et al.: Characterisation and prevalence of E. coli in confiscated meat samples

Bacteria $E$. coli was isolated from altogether 8 meat samples: from four fresh beef samples, three samples of frozen chicken meat, and one sample of fresh chicken meat, respectively. Altogether 6 isolates of $E$. coli that were further tested by ISO methods were not identified as O157 or STEC. Similar results were also obtained by KAUSHIK et al. (2018), where no E. coli O157 was found in poultry meat samples examined. Although it was not the case in our study, the majority of STEC or O157 E. coli was previously isolated from beef (HUSSEIN, 2007; NOBILI et al., 2017; VARCASIA et al. 2018).

Table 2. Antimicrobial susceptibility of $E$. coli isolates

\begin{tabular}{|c|c|c|c|c|c|c|}
\hline \multirow[b]{4}{*}{ Antimicrobial agent } & \multicolumn{6}{|c|}{ Origin } \\
\hline & \multicolumn{6}{|c|}{ E. coli isolates (sample ID) } \\
\hline & 1 & 2 & 3 & 4 & 5 & 6 \\
\hline & $\begin{array}{c}\text { Fresh } \\
\text { beef } \\
\text { meat }\end{array}$ & $\begin{array}{c}\text { Fresh } \\
\text { chicken } \\
\text { meat }\end{array}$ & $\begin{array}{c}\text { Fresh } \\
\text { chicken } \\
\text { meat }\end{array}$ & $\begin{array}{c}\text { Frozen } \\
\text { chicken } \\
\text { meat }\end{array}$ & $\begin{array}{l}\text { Fresh } \\
\text { beef } \\
\text { meat }\end{array}$ & $\begin{array}{l}\text { Fresh } \\
\text { beef } \\
\text { meat }\end{array}$ \\
\hline Gentamicin & $\mathrm{S}$ & $\mathrm{S}$ & $\mathrm{S}$ & $\mathrm{S}$ & $\mathrm{S}$ & $\mathrm{S}$ \\
\hline Amikacin & $\mathrm{S}$ & $\mathrm{S}$ & $\mathrm{S}$ & $\mathrm{S}$ & $\mathrm{S}$ & $\mathrm{S}$ \\
\hline Streptomycin & I & $\mathrm{S}$ & S & $\mathrm{S}$ & S & S \\
\hline Tobramycin & $\mathrm{S}$ & $\mathrm{S}$ & S & $\mathrm{S}$ & $\mathrm{S}$ & $\mathrm{S}$ \\
\hline Kanamycin & $\mathrm{S}$ & $\mathrm{S}$ & S & $\mathrm{S}$ & $\mathrm{S}$ & S \\
\hline Ampicillin & $\mathrm{S}$ & $\mathrm{S}$ & $\mathrm{S}$ & $\mathrm{S}$ & $\mathrm{S}$ & $\mathrm{S}$ \\
\hline Ceftazidime & $\mathrm{S}$ & $\mathrm{S}$ & $\mathrm{S}$ & $\mathrm{S}$ & $\mathrm{S}$ & $\mathrm{S}$ \\
\hline Aztreonam & $\mathrm{S}$ & $\mathrm{S}$ & $\mathrm{S}$ & $\mathrm{S}$ & $\mathrm{S}$ & $\mathrm{S}$ \\
\hline Amoxicillin & $\mathrm{S}$ & $\mathrm{S}$ & $\mathrm{S}$ & $\mathrm{S}$ & $\mathrm{S}$ & $\mathrm{S}$ \\
\hline Imipenem & $\mathrm{S}$ & $\mathrm{S}$ & $\mathrm{S}$ & $\mathrm{S}$ & $\mathrm{S}$ & $\mathrm{S}$ \\
\hline Cefotaxime & $\mathrm{S}$ & $\mathrm{S}$ & $\mathrm{S}$ & $\mathrm{S}$ & $\mathrm{S}$ & $\mathrm{S}$ \\
\hline Chloramphenicol & $\mathrm{S}$ & $\mathrm{S}$ & S & $\mathrm{S}$ & $\mathrm{S}$ & S \\
\hline Nalidixic acid & $\mathrm{S}$ & $\mathrm{S}$ & S & $\mathrm{S}$ & $\mathrm{S}$ & $\mathrm{S}$ \\
\hline Ciprofloxacin & $\mathrm{S}$ & $\mathrm{S}$ & $\mathrm{S}$ & $\mathrm{S}$ & $\mathrm{S}$ & S \\
\hline Sulphamethoxazole & $\mathrm{S}$ & $\mathrm{S}$ & $\mathrm{S}$ & $\mathrm{S}$ & $\mathrm{S}$ & $\mathrm{S}$ \\
\hline Sulphonamides & $\mathrm{R}$ & $\mathrm{S}$ & $\mathrm{S}$ & $\mathrm{S}$ & $\mathrm{S}$ & $\mathrm{S}$ \\
\hline Tetracycline & $\mathrm{R}$ & $\mathrm{S}$ & S & $\mathrm{R}$ & $\mathrm{S}$ & S \\
\hline Trimetoprim & $\mathrm{S}$ & $\mathrm{S}$ & $\mathrm{S}$ & $\mathrm{S}$ & $\mathrm{S}$ & $\mathrm{S}$ \\
\hline
\end{tabular}

Regarding antimicrobial susceptibility, one of the E. coli isolates, found in fresh beef meat, was resistant to sulphonamides and tetracycline, and intermediately resistant to streptomycin. Another isolate from frozen chicken meat was only resistant to tetracycline (Table 2). KAUSHIK et al. (2018) reported similar findings regarding the antimicrobial sensitivity of $E$. coli isolated from poultry meat, with the highest degree of susceptibility observed against gentamicin, amikacin and ciprofloxacin. However in our case, it 
was also susceptible to 11 other agents. It is known that in general organically raised chickens are less likely to be contaminated with antibiotic-resistant E. coli (DAVIS et al., 2018). Although we can only speculate about the origin of the meat (conventional or organic animal production), the lack of MDR E. coli in the examined samples could be related to the small scale family or organic production.

As previously described, the majority of illegal meat and meat products found at the border crossings of the Republic of Croatia were negative or contained only saprophytic or facultative pathogen bacteria (PRUKNER-RADOVČIĆ et al., 2014), so it may be concluded that the illegal import of food of animal origin represents only a minor risk for consumers. The highest number of the samples in this investigation were confiscated during the Christmas and Easter holidays and were mainly dry cured (processed) meat products. For such meat products it is known that, due to their low $\mathrm{pH}$ and water activity, they are only occasionally linked to food poisoning (CHACON et al., 2006). On the other hand, an outbreak of $E$. coli $\mathrm{O} 157: \mathrm{H} 7$ food poisoning occurred in the USA, when the consumers consumed dry-cured salami (ANONYM., 1995).

\section{Conclusion}

Although in the meat and meat samples confiscated at the Croatian borders no pathogenic or multidrug resistant $E$. coli was found, it could be reasonable to continue such monitoring for a longer period of time and on larger amount of samples, especially focusing on assessment of the persistence of pathogenic bacteria in dairy and fresh meat products. Also, there is a clear need for the use of modern molecular methods in such investigations, to be able to detect the subtypes, virulence and resistance of genes in the isolated bacteria.

\section{Acknowledgements}

This work was funded by Project no. FP7-KBBE-2010-4 No: 265877 - PROMISE "Protection of consumers by microbial risk mitigation through combating segregation of expertise". The authors are grateful to Mrs Ivančica Ivana Hustić Prelogar, Mrs Maja Štrkalj and Mrs Ana Konjević for their laboratory work, as well as the veterinary border officers for collecting the samples.

\section{References}

ANONYMOUS (1995): Escherichia coli O157:H7 outbreak linked to commercially distributed dry-cured salami-Washington and California, 1994. Morb. Mortal. Wkly. Rep. 44, 57-160 (Centers for Disease Control and Prevention).

ANONYMOUS (2001): ISO 16654:2001: Microbiology of food and animal feeding stuffs Horizontal method for the detection of Escherichia coli $\mathrm{O} 157$. 
D. Horvatek Tomić et al.: Characterisation and prevalence of E. coli in confiscated meat samples

ANONYMOUS (2008): Rapid Alert System for Food and Feed (RASFF). http://www.efet.gr/docs/ rasff/report2008 en.pdf

ANONYMOUS (2012a): Working document. Personal imports of meat and dairy products in Member States 2008-2011. https://ec.europa.eu/food/animals/animalproducts/personal_ imports_en

ANONYMOUS (2012b): ISO/TS 13136:2012 Microbiology of food and animal feed - Real-time polymerase chain reaction (PCR)-based method for the detection of food-borne pathogens Horizontal method for the detection of Shiga toxin-producing Escherichia coli (STEC) and the determination of O157, O111, O26, O103 and O145 serogroups.

ANONYMOUS (2017): The European Union summary report on trends and sources of zoonoses, zoonotic agents and food-borne outbreaks in 2016. EFSA J. 15 (12), 5077.

DOI: $10.2903 /$ j.efsa.2017.5077

ANONYMOUS (2018): The European Union Summary Report on antimicrobial resistance in zoonotic and indicator bacteria from humans, animals and food in 2016. EFSA Journal 16 (2), 5182.

DOI: $10.2903 /$ j.efsa.2018.5182

BEN SLAMA, K., A. JOUINI, R. BEN SALlEM, S. SOMALO, Y. SÁENZ, V. ESTEPA, A. BOUDABOUS, C. TORRES (2010): Prevalence of broad-spectrum cephalosporin-resistant Escherichia coli isolates in food samples in Tunisia, and characterization of integrons an antimicrobial resistance mechanisms implicated. Int. J. Food Microbiol. 137, 281-286.

DOI: 10.1016/j.ijfoodmicro.2009.12.003

BEUTLICH, J., J. A. HAMMERL, B. APPEL, K. NÖCKLER, R. HELMUTH, K. JÖST, M. L. LUDWIG, C. HANKE, D. BECHTOLD, A. MAYER-SCHOLL (2015): Characterization of illegal food items and identification of foodborne pathogens brought into the European Union via two major German airports. Int. J. Food Microbiol. 16, 13-19.

DOI: 10.1016/j.ijfoodmicro.2014.10.017

BROWN, A. E. (2005): Benson's Microbiological Applications: Laboratory Manual in General Microbiology. McGraw-Hill Companies Inc., New York. pp. 121-159.

CHABER, A. L., S. Allebone-WebB, Y. LignereuX, A. A. CUNNINGHAM, J. M. ROWCLIFFE (2010): The scale of illegal meat importation from Africa to Europe via Paris. Conserv Lett. 3, 317-323.

DOI: 10.1111/j.1755-263X.2010.00121.x

CHABER, A. L., A. A. CUNNIGHAM (2016): Public health risks from illegally imported african bushmeat and smoked fish. EcoHealth. 13, 135-138.

DOI: $10.1007 / \mathrm{s} 10393-015-1065-9$

CHACON, P. A., P. MUTHUKUMARASAMY, R. A. HOLLEY (2006): Elimination of Escherichia coli $\mathrm{O} 157: \mathrm{H} 7$ from fermented dry sausages at an organoleptically acceptable level of microencapsulated allyl isothiocyanate. Appl. Environ. Microbiol. 72, 3096-3102.

DOI: 10.1128/AEM.72.5.3096-3102.2006

Vet. arhiv 89 (1), 123-132, 2019 
D. Horvatek Tomić et al.: Characterisation and prevalence of E. coli in confiscated meat samples

CIOLACU, L., A. I. NICOLAU, M. WAGNER, K. RYCHLI (2015): Listeria monocytogenes isolated from food samples from a Romanian black market show distinct virulence profiles. Int. J. Food Microbiol. 16, 44-51.

DOI: 10.1016/j.ijfoodmicro.2014.08.035

DAVIS, G. S., K. WAITS, L. NORDSTROM, H. GRANDE, B. WEAVER, K. PAPP, J. HORWINSKI, B. KOCH, B. A. HUNGATE, C. M. LIU, L. B. PRICE (2018): Antibiotic-resistant Escherichia coli from retail poultry meat with different antibiotic use claims. BMC Microbiol. 18, 174-181.

DOI: $10.1186 / \mathrm{s} 12866-018-1322-5$

HUSSEIN, H. S. (2007): Prevalence and pathogenicity of Shiga toxin-producing Escherichia coli in beef cattle and their products. J. Anim. Sci. 85 (13 Suppl.), E63-72.

DOI: $10.2527 /$ jas.2006-421

JANSEN, W., M. MERKLE, A. DAUN, M. FLOR, N. T. GRABOWSKI, G. KLEIN (2016): The quantity and quality of illegally imported products of animal origin in personal consignments into the European Union seized at two German airports between 2010 and 2014. PLoS ONE 11(2): e0150023.

DOI:10.1371/journal.pone.0150023

JAKOBSEN, L., A. KURBACIS, L. SKJOT-RASMUSSEN, K. EJRNAES, L. J. PORSBO, K. PEDERSEN, L. B. JENSEN, H. D. EMBORG, Y.AGERSO, K. E. OLSEN, F. M. AARESTRUP, N. FRIMODT-MOLLER, A. M. HAMMERUM (2010): Escherichia coli isolates from broiler chicken meat, broiler chickens, pork, and pigs share phylogroups and antimicrobial resistance with community-dwelling humans and patients with urinary tract infection. Foodborne Pathog. Dis. 7, 537-547.

DOI: $10.1089 /$ fpd.2009.0409

JANS, C., E. SARNO, L. COLlineAU, L. MEILE, K. D. C. STÄRK, R. STEPHAN (2018): Consumer exposure to antimicrobial resistant bacteria from food at Swiss retail Level. Front. Microbiol. 9, 362.

DOI: $10.3389 /$ fmicb.2018.00362

KAUSHIK, P., A. ANJAY, S. KUMARI, S. DAYAL, S. KUMAR (2018): Antimicrobial resistance and molecular characterisation of E. coli from poultry in Eastern India. Vet. Ital. 54, 197-204.

NAGY, B., A. SZMOLKA, S. SMOLE MOŽINA, J. KOVAČ, A. STRAUSS, S. SCHLAGER, J. BEUTLICH, B. APPEL, M. LUŠICKY, P. APRIKIAN, J. PÁSZTI, I. TÓTH, R. KUGLER, M. WAGNER (2015): Virulence and antimicrobial resistance determinants of verotoxigenic Escherichia coli (VTEC) and of multidrug-resistant E. coli from foods of animal origin illegally imported to the EU by flight passengers. Int. J. Food Microbiol. 16, 52-59.

DOI: $10.1016 /$ j.ijfoodmicro.2015.06.026

NEWELL, D. G., M. KOOPMANS, L. VERHOEF, E., DUIZER, A. AIDARA-KANE, H. SPRONG, M. OPSTEEGH, M. LANGELAAR, J. THREFALL, F. SCHEUTZ, J. VAN DER GIESSEN, H. KRUSE (2010): Food-borne diseases -The challenges of 20 years ago still persist while new ones continue to emerge. Int. J. Food Microbiol. 139, 3-15.

DOI: 10.1016/j.ijfoodmicro.2010.01.021 
D. Horvatek Tomić et al.: Characterisation and prevalence of E. coli in confiscated meat samples

NOBILI, G., I. FRANCONIERI, G. LA BELLA, M. G. BASANISI, G. LA SALANDRA (2017): Prevalence of Verocytotoxigenic Escherichia coli strains isolated from raw beef in southern Italy. Int. J. Food Microbiol. 257, 201-205.

DOI: $10.1016 /$ j.ijfoodmicro.2017.06.022

PRUKNER-RADOVČIĆ, E., L. KOZAČINSKI, M. LUKAČ, S. GUTIĆ, D. HORVATEK TOMIĆ (2014): Foodborne pathogens in illegal imported food samples confiscated at the Croatian borders. Book of abstracts, PROMISE Meeting, 17-20 July, Hydra, Greece.

RODRÍGUEZ-LÁZARO, D., M. DIEZ-VALCARCE, R. MONTES-BRIONES, D. GALLEGO, M. HERNÁNDEZ, J. ROVIRA (2015): Presence of pathogenic enteric viruses in illegally imported meat and meat products to EU by international air travellers. Int. J. Food Microbiol. $16,39-43$.

DOI: $10.1016 /$ j.ijfoodmicro.2015.04.036

ROTH, N., A. KÄSBOHRER, S. MAYRHOFER, U. ZITZ, C. HOFACRE, K. J. DOMIG (2018): The application of antibiotics in broiler production and the resulting antibiotic resistance in Escherichia coli: A global overview. Poultry Sci. 0, 1-14.

DOI: $10.3382 / \mathrm{ps} /$ pey539

SÁENZ, Y., L. BRIŇAS, E. DOMÍNGUEZ, J. RUIZ, M. ZARAZAGA, J. VILA, C. TORRES (2004): Mechanisms of resistance in multiple-antibiotic-resistant Escherichia coli strains of human, animal, and food origins. Antimicrob. Agents Chemother. 48, 3996-4001.

DOI: 10.1128/AAC.48.10.3996-4001.2004

SUNDE, M. (2005): Prevalence and characterization of class 1 and class 2 integrons in Escherichia coli isolated from meat and meat products of Norwegian origin. J. Antimicrob. Chemother. 56, 1019-1024.

DOI: $10.1093 / \mathrm{jac} / \mathrm{dki} 377$

TAMMINEN, L. M., H. FRANSSON, M. TRÅVÉN, A. ASPÁN, S. ALENIUS, U. EMANUELSON, I. DREIMANIS, M. TÖRNQUIST, E. ERIKSSON (2018): Effect of on-farm interventions in the aftermath of an outbreak of hypervirulent verocytotoxin-producing Escherichia coli O157:H7 in Sweden. Vet. Rec. 5, 182, 516.

DOI: $10.1136 /$ vr.104223

VARCASIA, B. M., F. TOMASSETTI, L. DE SANTIS, F. DI GIAMBERARDINO, S. LOVARI, S. BILEI, P. DE SANTIS (2018): Presence of Shiga Toxin-Producing Escherichia coli (STEC) in Fresh Beef Marketed in 13 Regions of ITALY (2017). Microorganisms. 6 (4). pii: E126.

DOI: 10.3390/microorganisms6040126

WILSON D., G. DOLAN, H. AIRD, S. SORRELL, T. J. DALLMAN, C. JENKINS, L. ROBERTSON, R. GORTON (2018): Farm-to-fork investigation of an outbreak of Shiga toxinproducing Escherichia coli O157. Microb Genom. 4.

DOI: 10.1099/mgen.0.000160

Vet. arhiv 89 (1), 123-132, 2019 
D. Horvatek Tomić et al.: Characterisation and prevalence of $E$. coli in confiscated meat samples

Received: 28 October 2018

Accepted: 30 December 2018

\section{HORVATEK TOMIĆ, D.. L. KOZAČINSKI, M. LUKAČ, I. TOTH, S. GUTIĆ, E. PRUKNER-RADOVČ́IĆ: Struktura ilegalno uvezenoga mesa i mesnih proizvoda i pojavnost bakterije Escherichia coli u uzorcima zaplijenjenima na graničnim prijelazima Republike Hrvatske. Vet. arhiv 89, 123-132, 2019.}

\section{SAŽETAK}

Prevencija i kontrola bolesti uzrokovanih hranom među glavnim su ciljevima javnoga zdravstva diljem svijeta. Legalan uvoz hrane redovito se prati službenim kontrolama i o tome se redovito izvješćuje. S druge strane, hrana koja se nezakonito unese u zemlju mogla bi biti potencijalna prijetnja zdravlju potrošača. Kako bi se procijenila razina rizika za javno zdravstvo, ukupno 83 uzorka mesa i mesnih proizvoda različita podrijetla oduzeta su na šest graničnih prijelaza između Hrvatske i trećih zemalja. Posebna je pozornost bila usmjerena na prisutnost $E$. coli i njezinu antimikrobnu osjetljivost. Podrijetlo pošiljki bile su tzv. treće zemlje, a konačna destinacija zemlje EU-a i Švicarska. Težina zaplijenjenih pošiljki bila je od $500 \mathrm{~g}$ do $108 \mathrm{~kg}$. E. coli pronađena je u ukupno 8 zaplijenjenih pošiljki. Iako u ispitivanim uzorcima nisu pronađeni STEC/O157 ni multirezistentna E. coli, nezakonito unesenu hranu svakako treba kontinuirano pratiti i pregledavati kako bi se spriječilo širenje bakterijske infekcije uzrokovane hranom.

Ključne riječi: meso; konfiscirani uzorci; granični prijelazi; Escherichia coli 